\title{
Perspectives on Growth: Implications for Asia, Australia and New Zealand
}

\author{
Timothy M. Devinney and Stephen Kirchner
}

$\Gamma$ HiS article aims to identify the lessons that business people and policymakers in Australia, New Zealand and Asia should draw from the available evidence about economic development. It does not offer a complete answer to the question of what drives growth in developing economies, and Asian economies in particular. We outline some approaches to the theory of economic development, discuss some of the more compelling evidence, and draw a simple set of conclusions. We conclude by considering what these rules imply for Australia and a selection of Asian countries.

\section{Theories of Economic Development and Advantage}

Neoclassical theory and its endogenous offspring. Economists have traditionally followed the approach of Swan and Solow, which is based on traditional microeconomic notions of production functions and declining marginal rates of productivity. According to this approach (in its simplest form), growth is a function of four factors: the level of capital stock; the level of labour input; the productivity of capital; and the productivity of labour. Differences in growth are explained by reference to differences in the quantity and the quality of inputs. Natural limits to growth are set by the upper limits to productivity and inputs.

In one of the simplest expositions of the implications of this theory, ${ }^{2}$ Paul Krugman argues that Asian growth is almost entirely driven by inputs and is not sustainable over the long run without a fundamental alteration in the nature of the usage of inputs. The essence of his argument, as applied to Singapore, is represented by the data in Table 1 .

According to Krugman, Singapore's growth was driven by the improving utilisation of capacity: the rise in employed share of the population, the rise in savings and hence investment, and the increase in the quality of the labour input. But future

\footnotetext{
1 See Solow (1970) and Swan (1956).

${ }^{2}$ See Krugman (1994a) in Foreign Afrairs (March/April) and responses and rejoinder in the July/August issue of the same year. Further discussion of this and similar ideas can be found in Krugman (1994b) and Krugman (1996).
}

Timothy Devinney is Associate Professor of Management at the Australian Graduate School of Management, University of New South Wales. Stephen Kirchner is an economist with Standard \& Poor's MMS. 
growth is limited because (i) there is no longer any excess labour capacity (a fact reflected by increasing labour rates); (ii) there is almost no room for increasing the education level of Singaporeans $(99$ per cent of those under 40 years of age have a high-school degree); and (iii) savings rates of 40 per cent are almost impossible to sustain in the long run as a society ages and increases consumption.

Table 1: Factor inputs and growth in Singapore

\begin{tabular}{lll}
\hline & \multicolumn{1}{c}{1966} & 1990 \\
\hline $\begin{array}{l}\text { Annual percentage growth of } \\
\text { per capita GDP, 1966-90 }\end{array}$ & 8.5 \\
$\begin{array}{l}\text { Employed percentage share } \\
\text { of population }\end{array}$ & \multicolumn{1}{c}{27} & \multicolumn{1}{c}{51} \\
Education & $\begin{array}{l}\text { At least } 50 \% \text { had no } \\
\text { formal education }\end{array}$ & $\begin{array}{l}66 \% \text { had at least } 12 \\
\text { years of schooling }\end{array}$ \\
Investment & $\begin{array}{l}\text { 11\% of GDP in } \\
\text { savings }\end{array}$ & $\begin{array}{l}40 \% \text { of GDP in } \\
\text { savings }\end{array}$ \\
\hline
\end{tabular}

Source: Krugman (1994b).

But traditional growth theory, including Krugman's example as it relates to Singapore, fails to explain how and why rapid growth began when it did. Advocates of the 'factor accumulation model' attribute much of recent Asian growth to an exogenous shock in the form of the Plaza Accord of 1985, which increased the level of Japanese foreign direct investment in the area. Yet, although the rapid rise of the yen following this agreement by the major trading nations provides some explanation for spurt of development in the emerging economies of China, Thailand, Malaysia and Indonesia, it does little to explain the pre-1985 growth of Korea, Hong Kong, Singapore and Taiwan.

Modern variants of the theory have attempted to take into account factors other than 'pure' inputs as the ${ }_{3}$ causes of growth. What has come to be called 'endogenous' growth theory ${ }^{3}$ postulates that growth arises from random and purposeful developments or innovations within the economy. At one level, the theory simply accounts for the growth in technical and labour productivity that in earlier models had been assumed to be diminishing with factor accumulation or subject to random jumps. At a more sophisticated level, the theory attempts to account for purposeful and natural evolutionary changes in factor productivity.

Michael Porter's competitive advantage theory (the 'diamond'). Building on his highly successful articulation of the value chain and competitive advantage, Porter argues that growth arises from the interaction of the four fundamental forces pre-

\footnotetext{
${ }^{3}$ See Romer (1990); Krugman (1990); Shleifer (1986); Murphy et al. (1993).

${ }^{4}$ See, for example, Barro (1991).
} 
sented in Figure 1. Economic development is driven by the underlying sources of competitive advantage that emanate from these areas. In addition, as the economy evolves from being factor-driven to investment-driven and to innovation-driven, the sources of advantage change.

Figure 1: Porter's 'diamond' approach to growth

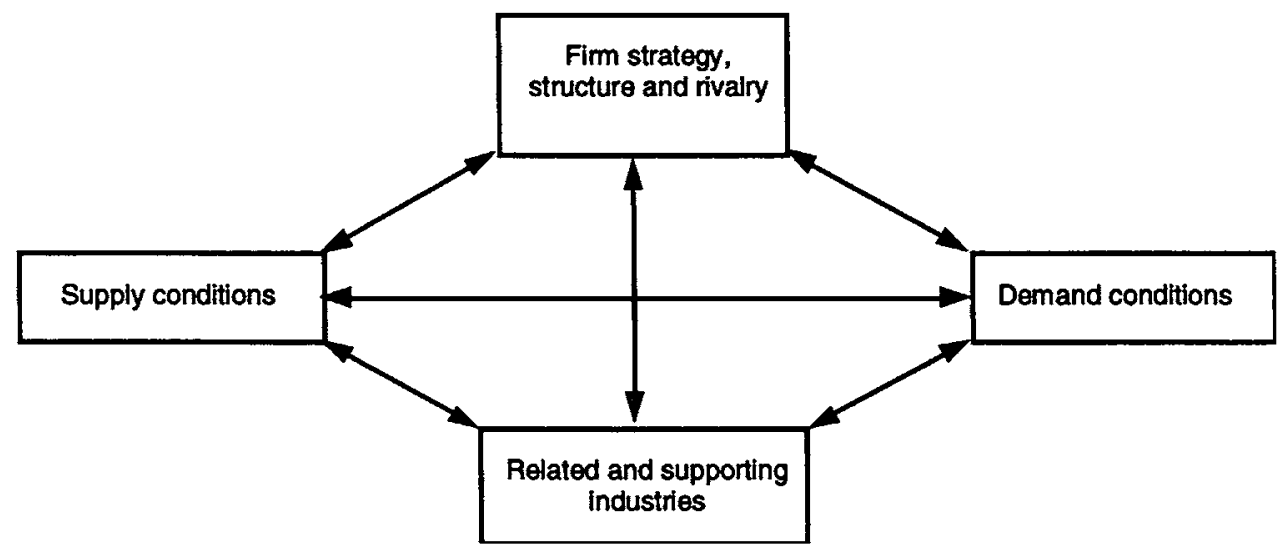

Source: Porter (1990:127).

According to Porter, early factor-driven growth arises from the circumstances in which a firm finds itself: countries like the United States and Australia, which are rich in natural resources, develop industries based on these endowments, whereas countries like Korea, Singapore and Japan, which are poor in natural resources, develop industries based on human capital. The second stage of growth occurs when resource expansion reaches its limits and investment is necessary to increase the productivity of existing factors of production. This is essentially a building stage of development, which most countries appear able to reach. Stage three requires real changes in the nature of development: innovation in management and technology, and sophistication of demand, replace investment and factor endowments as the future source of growth. Finally, some countries fail to sustain themselves in the innovation stage and enter the wealth stage, living off endowed and accumulated capital, thereby eroding their sources of advantage. Among Asian countries, Burma, Vietnam, China and India are in the first stage of development; Taiwan, Korea and Singapore have reached the investment stage; and Japan is at the innovation stage.

Porter's theory is certainly not rigorous and is unlikely to be falsifiable. However, it is something of a natural extension of traditional growth theory. First, it relies quite heavily on the notion of factor endowments as a source of trade and growth. Second, it focuses on the role that internal demand conditions play in setting the organisational and political agenda associated with the development of a commercial sector. Third, it highlights the importance of industry clusters and the role that externalities play in the development of an industry knowledge base. 
Macroeconomists had, for too long, been ignoring the importance of microeconomic industry structure, intra-country competition and role of the firm in affecting economic growth. Fourth, it allows us to begin talking about the role that innovation plays in driving growth. Traditional theory had, until recently, left the story off at investment.

In some sense, Porter's theory picks up from Schumpeter's (1939) notion of innovation as the real source of growth in an economy and merges it with his own blend of industrial organisation (which followed from Chandler's $[1962 ; 1990]$ ideas about industry and corporate evolution). Nor is it far from recent developments in endogenous growth theory discussed above. But, despite its immense appeal, its perhaps fatal weakness is that it is primarily a theory based on evidence gathered from developed economies (even though it has been applied to developing countries). Moreover, it is less a theory of economic growth than of how economies develop firms that can compete globally — for which task it is a reasonable theory.

The neo-institutional economics perspective. A third theory of growth stems from the neo-institutional economics literature associated with Douglass North (1990) and Mancur Olson (1996). This perspective holds that political and economic institutions, rather than factor endowments, are the fundamental determinants of growth. These institutions define the opportunity set and incentive structures at work in an economy. The most important institutions are those of private property, the rule of law and freedom of exchange (free trade). The right institutional framework allows economic actors to best capture the gains from trade. The wrong framework will encourage rent-seeking, speculation and other welfare-reducing activities.

For example, Olson (1996) notes that there is very little difference between the two Koreas in terms of their respective natural endowments, cultural traits or historical circumstances. The only plausible explanation of the vast difference between their incomes is their different political and economic institutions. More generally, Olson argues that this explains why differences in incomes between nations are so much greater than the differences between regions within countries: the nation-state, for better or worse, is that fundamental unit of institutional difference.

According to Olson, neither the old nor the new growth theories can explain why only a subset of low-income countries experience faster growth than both the developed countries and the other low-income countries. The explanation for this is that 'any poorer countries that adopt relatively good economic policies and institutions enjoy rapid catch-up growth: since they are far short of their potential (as Krugman argues), their per capita incomes can increase ... by narrowing the huge gap between their actual and potential income. Countries with the highest per capita incomes do not have the same opportunity' (Olson, 1996:20).

The evidence in support of the neo-institutional economics view is considerable. For example, Sachs and Warner (1995) find that economic growth in the newly industrialised economies is explained very well by economic openness, which is essentially an institutional variable. The fundamental lesson from the neoinstitutional economics literature, Olson argues, is that 'the best thing a society can 
do to increase its prosperity is to wise up' (1996:21). Growth is available to any society that is willing to adopt liberal social, economic and political institutions. What the neo-institutional economics literature has failed to address adequately to date is the fact that growth rates vary considerably over time but the institutional structures of many countries do not. ${ }^{5}$ We will address this issue shortly.

The World Bank's eclectic theory. The last theory is essentially an amalgamation of traditional and newer theories used by the World Bank in The Asian Miracle: Economic Growth and Public Policy (1993). The Bank concentrates on four areas: policy choices, competitive discipline, growth functions and outcomes. Its approach has become the standard explanation of the source of sustained growth in East Asia, and the basis of its guidance to other developing nations.

The World Bank's view of growth is related quite strongly to its agenda and mode of operation. Because the Bank deals with governments, it is hardly surprising that the theory puts emphasis on the role that the government plays in (i) setting up the economic environment; (ii) selectively intervening; (iii) establishing an appropriate bureaucratic infrastructure; and (iv) ensuring balanced distribution of economic rewards. It prescribes 'pragmatic conservatism' on the part of governments.

The World Bank's results from examining the economies of Taiwan, Korea, Japan, Indonesia, Hong Kong, Singapore, Malaysia and Thailand can explain about one-third of economic growth using primary and secondary education, investment, and population growth alone. Adding the relative position of these economies vis-àvis the US allows the Bank to claim that its model accounts for two-thirds of the growth in these economies. ${ }^{6}$ This result, among others, led the Bank to conclude that growth policy was best aimed at ensuring quality resource inputs, particularly in the case of labour.

The World Bank's analysis stops short of explaining the next source of growth for these economies. This is where Porter's approach and endogenous growth theory have some relevance. Indeed, we understand more about growth in rapidly developing economies (since our simple models seem to work better) than we do about the developed economies, where the natural limits of factor productivity have been reached. Future surges in growth become dependent not on the quantity of inputs but on their quality and how they are arranged. Explaining and predicting these facets of growth have proven to be difficult.

\section{Economic Development and Advantage: Evidence and Rules}

The role of input factors. The primary conclusion that arises from our discussion is that inputs play an important role in driving growth. The World Bank's findings are supported by Young (1994, 1995), who argues that the growth of Asian newly industrialising countries (NICs) is explained by labour-force participation

\footnotetext{
${ }_{6}^{5}$ See Easterly et al. (1993).

${ }^{6}$ We would like to thank an anonymous referee for pointing this out to us. The World Bank's analysis is not without its detractors, particularly those critical of its methodology and conclusions.
} 
rates, sectoral transfers into manufacturing, and investment, rather than by productivity increases that would be considered out of the ordinary. Some of Young's findings are presented in Table 2.

But how can such rapid increases in the cost of labour in NICs be sustainable in economic systems for which there is supposedly little or no technical progress? It is equally difficult to explain the differences in total factor productivity between countries where the expenditure on R\&D ranges from virtually nothing to almost 2 per cent of GDP and where the relationship between that investment and total factor productivity is weak at best. However, Young $(1994,1995)$ and Krugman $(1994 a, b)$ argue that, in most cases, growth and development are, more often than not, driven by more and better inputs rather than fewer inputs used in an extraordinary fashion. This is certainly one possibility. The important general point is that to understand growth it is necessary to look at the distribution and quantity of factor inputs first.

Table 2: Growth in output, productivity, and employment, and the level of R\&D

\begin{tabular}{lcccc}
\hline Country & $\begin{array}{c}\text { Average an- } \\
\text { nual \% growth } \\
\text { in mfg output } \\
\text { per worker } \\
1966-90\end{array}$ & $\begin{array}{c}\text { Average annual } \\
\text { \% growth in } \\
\text { total factor } \\
\text { productivity } \\
1966-90\end{array}$ & $\begin{array}{c}\text { Average an- } \\
\text { nual \% growth } \\
\text { in mfg } \\
\text { employment } \\
1966-90\end{array}$ & $\begin{array}{c}\text { Business } \\
\text { expenditure on }\end{array}$ \\
\hline Australia & 2.9 & 0.7 & -0.80 & $0.74(1994)$ \\
Hong Kong & 4.8 & 2.5 & 0.60 & na \\
India & 3.3 & 0.1 & 1.20 & $0.19(1992)$ \\
Japan & na & 1.2 & 2.35 & $1.87(1994)$ \\
Korea & 7.3 & 1.4 & 5.50 & $1.74(1993)$ \\
Malaysia & na & 1.0 & 0.04 & $0.46(1994)$ \\
Philippines & 2.8 & na & 1.50 & $0.01(1994)$ \\
Singapore & 2.8 & 0.1 & 5.70 & $0.75(1993)$ \\
Taiwan & 4.1 & 1.5 & 5.60 & $1.03(1994)$ \\
Thailand & 4.9 & 1.9 & 5.10 & $0.01(1994)$ \\
All other coun- & 3.2 & 1.9 & -0.59 & $1.10(1993)$ \\
tries & & & & \\
\hline Sourtes:Young & & & &
\end{tabular}

Sources: Young (1994); OECD, Main Science and Technology Indicators (various years).

The quality of inputs also appears to be important. Barro's (1991) study of 98 countries over 1960-85 found that quality of labour inputs, defined in terms of primary and secondary school enrolments and student-teacher ratios, is critical to growth. Coe and Helpman (1995) and Devinney (1996) find that innovation is a strong determinant of growth. Murphy et al. (1991), however, show that the rentseeking activities of law students are negatively related to growth.' Their further finding that the importance of education lies in where it is concentrated has drawn

\footnotetext{
They found that a 10 per cent increase in engineering graduates leads to a 0.5 per cent increase in growth while a 10 per cent increase in law graduates leads to 0.3 per cent decrease in growth.
} 
attention on the distribution and arrangements of inputs. Sachs and Warner (1997) show further that even quality can have its disadvantages: beyond some point the consumption side of human capital development (measured as life expectancy, literacy and schooling) comes to dominate the investment side, as the society has too many old poets and not enough young engineers.

The stability of growth. Within any ten-year period, the correlation between one year's growth and another year's is relatively high. However, the longer the time period, the lower is the correlation. This suggests that while recent growth is good at explaining 'near future' growth, it says virtually nothing about long-run growth. This is an interesting result since, as Easterly et al. (1993) note, political and social institutions are relatively stable over long periods of time. The theory that institutions are important to growth therefore does little to explain short-term fluctuations in growth.

One implication of these results is that a country must experience a spurt of growth over at least a decade or more to achieve sustainable growth. Equally important, development crises appear to occur when such transitions put pressure on the economy, society and political hierarchy. Policies that have validity under a factor accumulation regime are likely to have little validity under an innovation regime. The recent low growth rate of Japan, and the profound changes being imposed on South Korea by its entry into the OECD, may have much to do with those countries' positions in the development and growth life-cycle.

The importance of economic openness. Virtually every developing country makes approval of foreign direct investment conditional on export generation. However, the evidence suggests a strong relationship between economic growth and the share of GDP represented by both exports and imports. A recent table in Far Eastern Economic Review (10 October 1996) shows that the world's top exporters are also the world's top importers, implying that growth depends on openness. Exportdriven growth is important, but the benefits of openness lie not in trade as such but in the discipline and open institutional structures that accompany it. But, with some minor exceptions (such as Luxembourg, Bahrain, Hong Kong and Singapore), most nations are predominantly closed since they naturally trade most with their closest neighbours. Hence the extremely strong positive relationship that is found between the size of a country, the number of bordering countries, and its openness to trade (Dowrick, 1994).

In general, the economic openness of the average economy increased by 28 per cent between 1960-65 and 1985-92. The openness measure of Korea, Japan, Indonesia, the Philippines, Malaysia and Thailand increased from 35 per cent in 1960-65 to 70 per cent in $1985-92$. However, during that same period the measure for all other countries increased from 53 per cent to 68 per cent. The ranking of countries did not greatly change over time: a country that was relatively closed in 1965 was likely to be relatively closed in 1992 .

\footnotetext{
${ }^{8}$ Data from Penn World Tables at http://datacentrc.epas.utoronto.ca:5680/pwt/pwthtml.
} 
The role of institutions. The role of government and the value of democratic institutions have received much attention in recent years. The World Bank notes that intervention sometimes seems to work; but it remains non-committal on the role of industrial policy. Other commentators, most notably Lester Thurow $(1992,1996)$ and Tyson (1993), advocate Japanese-style industrial policy as a source of growth. The evidence is mixed. Government involvement in the economy (as measured by its share of GDP) is indeed negatively related to growth but the variance is so large as to make any substantial conclusion moot. ${ }^{9}$ Indeed, those countries with the lowest growth rates are more, not less, likely to have low government shares of GDP.

However, the Heritage Foundation's index of economic freedom (Johnson \& Sheehy, 1995) ${ }^{10}$ suggests that the link between economic freedom and economic growth is quite positive. This result is supported by Mauro's (1995) detailed study of the relationship between corruption and growth, which found that about 20 per cent of growth was explained by the presence or absence of corruption. "I For example, based on his evidence, if India could reduce its corruption level to that of Italy its investment is estimated to increase by 4.87 per cent of GDP and its growth by 0.5 per cent a year.

What really matters? Development economists seem frustratingly unable fully to capture the complexity of the phenomena they wish to characterise. Growth may be dependent on the quality of factor inputs or economic institutions; but what are the appropriate measures? In a recent paper titled 'I Just Ran Two Million Regressions', Sala-I-Martin (1997) examines the relationship between growth and nine sets of variables based on regions, politics, religion, market distortions and performance, investment, industry production, economic openness, economic organisation, and whether or not the country was a former Spanish colony. From all this it can be concluded that Protestant/Catholic, closed, socialist ex-Spanish colonies located close to the equator that are relatively resource-rich but are suffering from revolutions and wars and must deal with a black market premium on their currency will have poorer growth than countries not possessing these characteristics.

Faced with these difficulties, simple rules should dominate until such time as better information allows more complex rules to be formulated. Our prior discussion suggests that all the research to date supports three almost common-sense

\footnotetext{
${ }^{9}$ Every study we have seen has shown a partial correlation coefficient between growth and government expenditure. The magnitude and significance of the coefficients are strongly effected by the structure of the models employed. 10

The index includes measures of tax burden, trade policy, government consumption, monetary policy, foreign investment rules, banking rules, wages and price restrictions, property rights protection, regulation and the existence of a black market. Easton \& Walker (1997) provide detail on the relationship between this measure and growth.

Mauro's index does not include assassinations, coups, government spending and general political instability, all of which are clearly related to corruption.
} 
rules: factor accumulation is good; open economic systems and institutions are good; and persistence in these two rules is critical.

\section{Lessons for Australia, New Zealand and Asia}

What does this information imply for Australia, New Zealand and developing Asian nations? Table 3 presents a number of key indicators for Australia, New Zealand, Malaysia and India. The first three represent a reasonable comparison of resourcerich but small-population countries. India and Malaysia are examples of countries at different levels of development, with different developmental difficulties.

Table 3: Economic and social indicators: rankings for Australia, New Zealand, Malaysia and India

\begin{tabular}{|c|c|c|c|c|c|}
\hline Indicator & Australia & $\begin{array}{c}\text { New } \\
\text { Zealand }\end{array}$ & Malaysia & India & Source \\
\hline $\begin{array}{l}\text { Trade } \\
\text { Taxation } \\
\text { Government consumption } \\
\text { Monetary policy } \\
\text { Foreign investment } \\
\text { Banking } \\
\text { Wages/prices } \\
\text { Property rights } \\
\text { Regulation }\end{array}$ & $\begin{array}{l}2 \\
4 \\
3 \\
2 \\
2 \\
1 \\
2 \\
1 \\
3\end{array}$ & $\begin{array}{c}\mathrm{nr} \\
\mathrm{nr} \\
\mathrm{nr} \\
\mathrm{nr} \\
\mathrm{nr} \\
\mathrm{nr} \\
\mathrm{nr} \\
\mathrm{nr} \\
\mathrm{nr}\end{array}$ & $\begin{array}{c}3 \\
2.5 \\
2 \\
1 \\
2 \\
3 \\
2 \\
2 \\
2\end{array}$ & $\begin{array}{l}5 \\
5 \\
3 \\
2 \\
3 \\
4 \\
2 \\
3 \\
4\end{array}$ & $\begin{array}{l}\text { JS } \\
\text { JS } \\
\text { JS } \\
\text { JS } \\
\text { JS } \\
\text { JS } \\
\text { JS } \\
\text { JS } \\
\text { JS }\end{array}$ \\
\hline $\begin{array}{l}\text { Domestic economy } \\
\text { Finance } \\
\text { Infrastructure } \\
\text { Management } \\
\text { Science \& technology } \\
\text { People (education, etc.) }\end{array}$ & $\begin{array}{c}18 \\
15 \\
6 \\
25 \\
42 \\
31\end{array}$ & $\begin{array}{l}10 \\
16 \\
7 \\
7 \\
22 \\
13\end{array}$ & $\begin{array}{c}7 \\
19 \\
22 \\
15 \\
29 \\
34\end{array}$ & $\begin{array}{l}32 \\
30 \\
43 \\
32 \\
33 \\
44\end{array}$ & $\begin{array}{l}\text { IMD } \\
\text { IMD } \\
\text { IMD } \\
\text { IMD } \\
\text { IMD } \\
\text { IMD }\end{array}$ \\
\hline Judiciary system & 10 & 10 & 9 & 8 & BIC (mean \\
\hline Red tape & 9.25 & 10 & 6 & 3.25 & $\begin{array}{l}\mathrm{BIC} \text { (mean } \\
=6.37 \text { ) }\end{array}$ \\
\hline Corruption & 10 & 10 & 6 & 5.25 & $\begin{array}{l}\mathrm{BIC} \text { (mean } \\
=6.99)\end{array}$ \\
\hline Political stability & 8.5 & 8.5 & 8.42 & 7.0 & $\begin{array}{l}\mathrm{BIC} \text { (mean } \\
=7.61)\end{array}$ \\
\hline $\begin{array}{l}\text { Ethnolinguistic fractionali- } \\
\text { sation }\end{array}$ & $\overline{32}$ & $\overline{37}$ & 72 & 89 & $\begin{array}{l}\text { ANM (mean } \\
=34.6 \text { ) }\end{array}$ \\
\hline
\end{tabular}

Sources: JS: Johnson \& Sheehy, The Index of Economic Freedom, Heritage Foundation, Washington DC, 1995. Ranking: $1=$ best.

IMD: World Competitiveness Yearbook, IMD, Lausanne, 1996. Ranking out of 45; $1=$ best.

BIC: Business International Corporation, Introduction to Country Assessment Services, New York, 1984 (as updated). Ranking: 10 = best.

ANM: Atlas Narodov Miro, Department of Geodesy and Cartography of the State Geological Committee of the USSR, 1964. 'Ethnolinguistic fractionalisation' measures the probability that any two people will not be from the same ethnolinguistic group. 
For Australia, three main conclusions appear to follow from this information. First, Australia does relatively well in terms of the rule of law, political stability, corruption and property rights. Second, its performance is relatively mediocre in the areas of taxation, regulation and government involvement: Australia tends to overly manage economic interactions (although it does protect them). ${ }^{12}$ Third, there are serious concerns about the quality of Australian inputs. In the fields of management, people, and scientific achievement it performs poorly relative to other OECD countries.

New Zealand provides an interesting contrast to Australia. Although it was excluded from the Heritage Foundation's survey of economic freedom, a fairly clear picture of it emerges from the remaining sources. On most measures of institutional structure ('red tape', for example), New Zealand is equal to or slightly better than Australia. But differences appear in the managerial and economic indicators most directly related to the degree of competitiveness of the economy. Faced with dismal economic prospects, New Zealand has undertaken structural adjustment much earlier, and to a greater degree, than Australia. Future growth is related less to institutional change than to the development of human capital resources to match an increasingly free domestic market.

Malaysia has made it quite clear that it will continue to follow the 'Singapore model'. Perhaps most interesting about Malaysia are its quite high economic freedom rankings (apart from trade and banking). Its recent plans for a high-tech corridor and its investments in education and infrastructure development imply that it understands clearly the importance of high-quality inputs to a country with a small population relative to its neighbours and competitors. The country has also successfully developed its domestic economy rather than relying on exports alone. Malaysia's difficulties arise from two areas: an unwillingness to move up the 'economic freedom' ladder (where it occupies the middle) and its high level of ethnolinguistic fractionalisation. The politics of such a diverse society has concentrated decision-making authority in a way that naturally creates red tape and opportunities for corruption and rent-seeking.

For India, the prospects are not so bright. There are serious problems with corruption and government intervention, taxation, banking and trade restrictions. India appears to violate of the first and second of our rules of development (factor accumulation and open institutions). It further suffers from a diverse ethnic composition and poor performance in all the indicators used in the World Competitiveness Report. Internal difficulties reflecting its ethnic diversity have made it unwilling politically to follow strategies that are sustainable (in violation of our third rule of development). As well, unlike many nations of East Asia, India, because of its population and geographic size, is a relatively closed economy (about 17 per cent of GDP comprises exports and imports, compared with an average of 72 per cent

\footnotetext{
${ }^{12}$ In some related work we have estimated that the Australian economy's growth rate is reduced by 1.6 per cent a year due to excessive regulation: see Colvin, Devinney \& Kirchner (1997). This is significant, since annual average real growth in GDP(A) since the March quarter 1972 has been 3.2 per cent.
} 
for the rest of the world and 20 per cent for the US). Growth should not be sought primarily from export promotion since so much more can be gained from reforming the domestic economy. For India, policy prescriptions are much clearer than for Australia (or even Malaysia) because they are so basic: growth follows from consistency in the development of inputs to production and the easing of restrictions on economic freedom, allowing the domestic economy to flourish.

\section{Conclusion}

The general applicability of the rules we have developed for promoting growth is evident for all the developed and developing countries of Asia. The basic conclusion is that high-quality inputs (capital, labour and technology) that are quickly and efficiently processed by high-quality institutions, infrastructure and managers will, in general, produce the quality goods. It is odd that so much policy discussion fails to recognise the simplicity and robustness of this fact.

\section{References}

Barro, R. (1991), 'Economic Growth in a Cross Section of Countries', Quarterly Journal of Economics 106: 407-44.

Chandler, A. (1962), Strategy and Structure, MIT Press, Cambridge, Mass.

— \& H. Takashi (1990), Scale and Scope: Dynamics of Industrial Capitalism, Belknap Press, Cambridge, Mass.

Coe, D. \& R. Helpman (1995), 'International R\&D Spillovers', European Economic Review 39: 85987.

Colvin, J., T. Devinney \& S. Kirchner (1997), 'As Law and Regulation Grows, So Economic Development Slows', Business Review Weekly, 17 February: 57-8.

Devinney, T. (1996), Characterising International Patent Behaviour, University of New South Wales, Sydney (unpublished working paper).

Dowrick, S. (1994), 'Openness and Growth', pp. $9-41$ in P. Lowe \& J. Dwyer (eds), International Integration of the Australian Economy, Reserve Bank of Australia, Sydney:

Easterly, W., M. Kremer, L. Prichett \& L. Summers (1993), 'Good Policy or Good Luck? Country Growth Performance and Temporary Shocks', Journal of Monetary Economics 32: 459-83.

Easton, S. \& M. Walker (1997), 'Income Growth and Economic Freedom', American Economic Review 87: 328-32.

Johnson, B. \& T. Sheehy (1995), The Index of Economic Freedom, Heritage Foundation, Washington DC.

Krugman, P. (1990), Rethinking International Trade, MIT Press, Cambridge, Mass.

— (1994a), 'Competitiveness: A Dangerous Obsession', Foreign A/fairs 73(2): 28-44.

(1994b), 'The Myth of Asia's Miracle', Foreign Affairs 73(6): 62-78. 
— (1996), Pop Internationalism, MIT Press, Cambridge, Mass.

Mauro, P. (1995), 'Corruption and Growth', Quarterly Journal of Economics 110: 681-712.

Murphy, K., A. Shleifer \& R. Vishny (1991), 'The Allocation of Talent: Implications for Growth', Quarterly Joumal of Economics 106: 503-30.

— (1993), 'Why Is Rent Seeking So Costly to Growth?", American Economic Review 83: 409-14.

North, D. (1990), Institutions, Institutional Change, and Economic Performance, Cambridge University Press, New York.

Olson, M. (1996), 'Big Bills Left on the Sidewalk: Why Some Nations are Rich and Others Poor', Joumal of Economic Perspectives 10: 3-24.

Porter, M. (1990), The Competitive Advantage of Nations, Free Press, New York.

Romer, P. (1990), 'Endogenous Technical Change', Journal of Political Economy 98(October) (part 2): s71-102.

Sachs, J. \& A. Warner (1995), 'Economic Reform and the Process of Global Integration', Brookings Papers on Economic Activity, Macroeconomics 1: 1-118.

- (1997), 'Fundamental Sources of Long-Run Growth', American Economic Review 87: 184-8.

Sala-I-Martin, X. (1997), 'I Just Ran Two Million Regressions', American Economic Review 87: 17883.

Schumpeter, J. (1939), Theory of Economic Development, Harvard University Press, Cambridge, Mass.

Shleifer, A. (1986), 'Implementation Cycles', Joumal of Political Economy 94: 1163-90.

Solow, R. (1970), Growth Theory: An Exposition, Clarendon Press, Oxford.

Swan, T. (1956), 'Economic Growth and Capital Accumulation', Economic Record 32: 334-61.

Thurow, L. (1992), Head to Head, William Morrow, New York.

(1996), The Future of Capitalism, William Morrow, New York

Tyson, L. (1993), Who's Bashing Whom?, Institute for International Economics, Washington DC.

World Bank (1993), The East Asian Miracle: Economic Growth and Public Policy, Oxford University Press, New York.

Young, A. (1994), 'Lessons from East Asian NICs: A Contrarian View', European Economic Review 38: 964-73.

- (1995), "The Tyranny of Numbers: Confronting the Statistical Realities of the Fast Asian Growth Experience', Quarterly Journal of Economics 110: 641-80. 